Sharikov, V., Kireeva, Y., Akchulpanov, Y., Gribova, N., \& Berketova, L. (2021). Socio-economic aspects of the development of the tourism and hospitality industry in the Russian Federation. Amazonia Investiga, 10(42), 43-55. https://doi.org/10.34069/AI/2021.42.06.5

\title{
Socio-economic aspects of the development of the tourism and hospitality industry in the Russian Federation
}

\section{Социально-экономические аспекты развития индустрии туризма и гостеприимства в Российской Федерации}

Received: April 30, 2021

\begin{abstract}
This trend has affected both tourist countries and countries where tourism is not the primary economic sector. This paper examines the socio-economic aspects of the development of the Russian Federation's tourism industry in recent years. The objective of the study is to evaluate the development of the tourism industry in Russia. For this purpose, the issues of methodology for collecting official statistical information in tourism are considered, statistical data on tourism development are analyzed, and key indicators of the Tourism Development Strategy in the Russian Federation for the period up to 2035 are analyzed. The authors used general scientific research methods, namely, methods of reviewing the economic literature on the stated topic, analyzing statistical data characterizing the development of tourism in the Russian Federation in 2014-2018, and synthesizing the results obtained. The data source was indicators characterizing the development of the tourism and hospitality industries in Russia, the activities of collective accommodation
\end{abstract}

Accepted: June 10, 2021

Written by:

Valentin Sharikov ${ }^{19}$

https://orcid.org/0000-0003-2557-5153

Yulia Kireeva ${ }^{20}$

https://orcid.org/0000-0003-0866-0196

Yulay Akchulpanov ${ }^{21}$

https://orcid.org/0000-0002-5233-9036

Natalya Gribova ${ }^{22}$

https://orcid.org/0000-0002-8440-5325

Lydia Berketova $^{23}$

https://orcid.org/0000-0002-1798-6131

\footnotetext{
${ }^{19}$ Associate Professor, Russian State University of Physical Education, Sport, Youth And Tourism (SCOLIPE), Russia.

${ }^{20}$ Associate Professor, Russian State University of Tourism and Service, Russia.

${ }^{21}$ Academic Secretary, Institute for Strategic Studies of the Republic of Bashkortostan, Russia.

${ }^{22}$ Assistant Professor, Plekhanov Russian University of Economics, Russia.

${ }^{23}$ Assistant Professor, Plekhanov Russian University of Economics, Russia.
} 
facilities, and tourist companies. The study describes the social and economic aspects of the development of the tourism and hospitality industries in Russia for 2014-2018, identifies the necessary organizational and economic conditions to increase the volume of domestic tourism through administrative, fiscal, and social measures, proposes mechanisms to stimulate national tourism development to achieve the key indicators of tourism development until 2035.

Keywords: tourism, tourism industry, hospitality industry, tourist product, tourist market.

\section{Introduction}

In the context of the global spread of coronavirus infection, one of the most affected areas of the world and the Russian economy is the tourism and hospitality industry. This is primarily because the tourism and hospitality industry has a multiplier effect, which is reflected in the stimulating effect on the economy's related sectors. However, in times of crisis, this factor also plays the opposite, negative role - other businesses and organizations of the tourism and hospitality industry suffer along the chain (Burns, 1998).

In Russia, tourism plays a vital role in the economy; for example, the creation of 1 job in the tourism industry entails the creation of up to 5 jobs in the economic sectors related to tourism, and every 1,000 tourists account for the creation of up to 13 jobs in the country's economy. The average annual growth rate of the tourism industry in Russia in recent years was approximately 7\%. From 2014 to 2018, the number of tourist trips increased by 1.5 times and amounted to 96.1 million trips (Directive № 2129-R, 2019).

According to experts, Russia is a country with a vast tourism potential that has yet to be fully exploited (Andrades \& Dimanche, 2017). However, the development of tourism in Russia also faces serious problems, namely:

1) poorly developed road and tourism infrastructure in general (Andrades \& Dimanche, 2017);

2) low level of staff quality in the tourism industry, problems in staff training and education (Briedenhann \& Wickens, 2004; Poddubnaya et al., 2020); коллективных средств размещения; деятельность туристских фирм. В результате исследования даётся характеристика социальных и экономических аспектов развития индустрии туризма и гостеприимства в России за 2014-2018 гг., определяются необходимые организационно-экономические условия увеличения объёмов внутреннего туризма за счёт мер административного, налогового и социального характера, предлагаются механизмы, стимулирования развития национального туризма в целях достижения ключевых индикаторов развития туризма до 2035 г.

Ключевые слова: туризм, сфера туризма, сфера гостеприимства, туристский продукт, туристский рынок.

3) low-quality management in the tourism industry (Chibir and Shirko, 2015).

This study aims to assess the development of the tourism industry in Russia in recent years. The following tasks are set within the framework of this study to achieve this objective:

1) to consider the methodology of collecting official statistical information in tourism to assess its adequacy to modern realities;

2) to analyze statistical data on the Russian tourism development to study the trends and state of the industry;

3) to analyze the key indicators of the Tourism Development Strategy in the Russian Federation for the period up to 2035 to compare the state's goals and objectives in the tourism industry and the current state of affairs.

\section{Literature Review}

In most countries of the world, tourism is recognized as a high-income industry, and in several countries, tourism is the primary source of revenue to the state budget. Tourism specialists regularly study the impact of tourism on the economy of a country or a particular region. The authors consider both the positive and negative effects of tourism on the economy, but generally emphasize the positive impact of tourism development on economic development, the well-being of the population, and poverty reduction (Chen \& Chiou-Wei, 2009; Croes \& Venegas, 2008; Holzner, 2011; Tang \& Tan, 2015). 


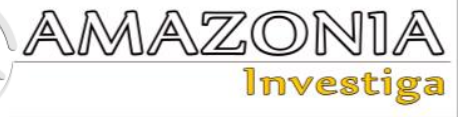

However, according to Matarrita-Cascante (2010), despite the positive effect of tourism development, local residents are not always ready for the upcoming changes, becoming a point of tension in this area. According to Tugcu (2014), tourism does not always lead to economic growth. Tugcu, having analyzed panel data on tourism in Europe, Asia, and Africa bordering the Mediterranean Sea for 19982011, concluded a bidirectional causal relationship between tourism development and economic growth in Europe, Asia, and the Mediterranean region. However, there is no such causal relationship in Africa. Brida, Matesanz, and Segarraa (2020) also write about the heterogeneous impact of tourism on economic growth. The analysis of the dynamics of economic growth and tourism development in 80 countries over 1995-2016 showed that they were heterogeneous. In this regard, countries with a high and low degree of interdependence were identified.

As for research in the field of tourism in Russia, the following areas can be distinguished. The first direction is research in tourism development and its strategy (Konovalova et al., 2018; Kulgachev et al., 2018; Yudina and Bushueva, 2020; Fedorova et al., 2020). Konovalova et al. (2018), which, based on Russia's tourism industry analysis, proposed a strategic model for its development. The study highlights the negative impact of the imposed international sanctions on Russia, namely the negative impact on the country's image.

Kulgachev et al. (2018) summarized statistical data on the main indicators characterizing Russia's inbound tourism development. Based on the analysis results, the following conclusions were formulated:

- the main tourist centers receiving foreign tourists are the federal cities of Moscow and St. Petersburg;

- educational and business purposes are the main goals of foreign tourists visiting the tourist regions of the Russian Federation;

- according to the statistics of the World Tourism Organization (UNWTO) in 20002016, the number of tourists that arrived in Russia increased by 1.45 times (from 22 to 32 million);

- the method of statistical accounting of tourists used in Russia is not perfect, does not give a complete and reliable picture of the tourist flow.
In Russia, tourism has recently been officially recognized as an industry that generates income for the state. In this regard, the Russian tourism industry is undergoing significant changes related to tourism management, the development, and implementation of a tourism development strategy, the distribution of state support for implementing the most promising projects in the regions, etc. These issues are discussed in detail in various works of Russian authors. For example, Yudina and Bushueva (2020) analyzed the state policy in tourism development in the framework of the Tourism Development Strategy in the Russian Federation for the period until 2035 .

The second research area in Russian tourism concerns cross-border tourism. Cross-border tourism between Russia and Poland is discussed in a study by Studzienieckia et al. (2016). Cross-border cooperation and the availability of "small border traffic" significantly increase the volume of cross-border tourism. Cross-border tourism between Russia and Finland is described in the Jakosuo (2011) study. The Jakosuo study states that the development of cross-border infrastructure has a positive impact on mutual tourist flows. Trade tourism between Russia and China is considered in Zhao (1994), scientific tourism between Russia and Finland in Makkonenab et al. (2018).

The third research area in the field of tourism is aimed at studying how to turn tourism into a high-budget branch of the Russian economy at the present stage and meet the needs of current and future generations for recreation, improving the quality of life of the population and maintaining the health of citizens (Chibir and Shirko, 2015; Gorbuntsova et al., 2019; Gorbunov et al., 2018).

Sustainable tourism development is also increasingly becoming a subject of study as one of the priority areas for solving various problems that arise in the process of tourism development. Almost all countries have developed sustainable tourism development programs that identify problem areas and offer solutions. The principles of sustainable tourism development are taken into account when planning and implementing the activities of tourism administrations in tourism. Programs have resulted in environmental protection, more conferences, meetings, workshops, and fewer conflicts involving local people and tourists (Andrades \& Dimanche, 2017). 
The implementation of sustainable tourism development principles allows increasing the competitiveness of Russia as a tourist destination. The issues of improving the competitiveness of the Russian tourist product, individual tourist services, and the principles of sustainable tourism development in full is one of the currently relevant topics discussed at various levels (Bianchi, 2018).

\section{Methods}

The study was conducted in the following phases:

1. First of all, international and Russian academic literature on the impact of tourism on the development of the country's economy was studied.

2. Then the results of tourism development in Russia for 2011-2018 were analysed. The data source was based on the data portal of the Federal Agency for Tourism of the Russian Federation (2020).

3. Then the target indicators of tourism development in Russia until 2035 were determined. The main data were taken from the Strategy of tourism development in the Russian Federation for the period until 2035.

4. As a result of the study, the conclusions on the research topic were formulated and compared with the conclusions of other scholars.
The following general scientific research methods were used to prepare this study:

- analysis of the scientific literature on the stated topic;

- analysis of statistical data describing the development of tourism in the Russian Federation for 2014-2018;

- $\quad$ synthesis and generalization of the obtained results.

\section{Results and Discussion}

In 2009-2010 in Russia, the state staked on the development of inbound and domestic tourism. To achieve the corresponding indicators in Russia, the Federal Target Program (hereinafter FTP) "Development of domestic and inbound tourism in the Russian Federation (2011-2018)" was developed and adopted for implementation (Resolution No.644, 2011).

The main goal of the FTP was to increase the level of competitiveness of the Russian tourist market by developing the tourist and recreational complex, improving the quality of tourist services, and promoting national tourist products in the domestic and international tourist markets.

Target indicators for implementing this FTP were identified, which were required to be achieved by 2018. According to the results of the FTP implementation, the following results were achieved (Table 1).

Table 1.

Target indicators for implementing of Federal Target Program "Development of domestic and inbound tourism in the Russian Federation (2011-2018)"

\begin{tabular}{|c|c|c|c|c|c|}
\hline $\begin{array}{l}\text { Pack } \\
\text { No. }\end{array}$ & Indicator & $\begin{array}{l}\text { Plan for } \\
2018\end{array}$ & $\begin{array}{l}\text { Fact for } \\
2018\end{array}$ & $\begin{array}{l}\text { Fact of the } \\
\text { plan, \% }\end{array}$ & $\begin{array}{l}\text { Plan } \\
\text { implementation, } \\
\text { yes/no }\end{array}$ \\
\hline 1. & $\begin{array}{l}\text { Number of citizens of the Russian Federation } \\
\text { placed in collective accommodation facilities } \\
\text { (CAF), million people }\end{array}$ & 35 & 62.2 & 177.7 & Yes \\
\hline 2. & $\begin{array}{l}\text { Number of foreign citizens placed in CAF, million } \\
\text { people }\end{array}$ & 8.7 & 11.5 & 132.2 & Yes \\
\hline 3. & $\begin{array}{l}\text { CAF room fund area, thousand sq. m. } \\
\text { Investments in fixed assets of accommodation }\end{array}$ & 16,192 & 21,649 & 133.7 & Yes \\
\hline 4. & $\begin{array}{l}\text { facilities (hotels, places for temporary residence), } \\
\text { million rubles }\end{array}$ & $23,815.5$ & 42,861 & 180.0 & Yes \\
\hline 5. & Number of beds in the CAF, thousand units & 1452 & $2,414.5$ & 166.3 & Yes \\
\hline 6. & $\begin{array}{l}\text { Number of people working in CAF, thousand } \\
\text { people }\end{array}$ & 573.5 & 325.0 & 56.7 & No \\
\hline 7. & $\begin{array}{l}\text { Number of people working in travel agencies, } \\
\text { thousand people }\end{array}$ & 48 & 66.7 & 139.0 & Yes \\
\hline 8. & $\begin{array}{l}\text { Volume of paid tourist services rendered to the } \\
\text { population, billion rubles }\end{array}$ & 178 & 172.1 & 96.7 & No \\
\hline 9. & $\begin{array}{l}\text { Volume of paid services of hotels and similar } \\
\text { accommodation facilities, billion rubles }\end{array}$ & 220.5 & 255.7 & 116.0 & Yes \\
\hline
\end{tabular}

Source: Federal Agency for Tourism of the Russian Federation, 2020 


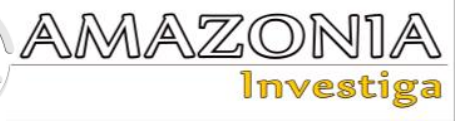

Thus, it can be concluded that the target indicators for the FTP 2011-2018 were achieved and exceeded, in addition to the volume of paid tourist services and the number of people working in the CAF.

In 2019, the Directive № 2129-R (2019) approved the Strategy of Tourism Development in the Russian Federation for the period until 2035 (hereinafter referred to as the Strategy). In accordance with this document, the development of national tourism is carried out today based on an integrated approach. To achieve the Strategy goals, the necessary conditions will be created to promote highquality and competitive tourist products in the domestic and international tourist markets, strengthen the social role of tourism, and ensure the availability of tourist services and recreation for Russian citizens.

The key indicators of the Strategy are shown in Figure 1.

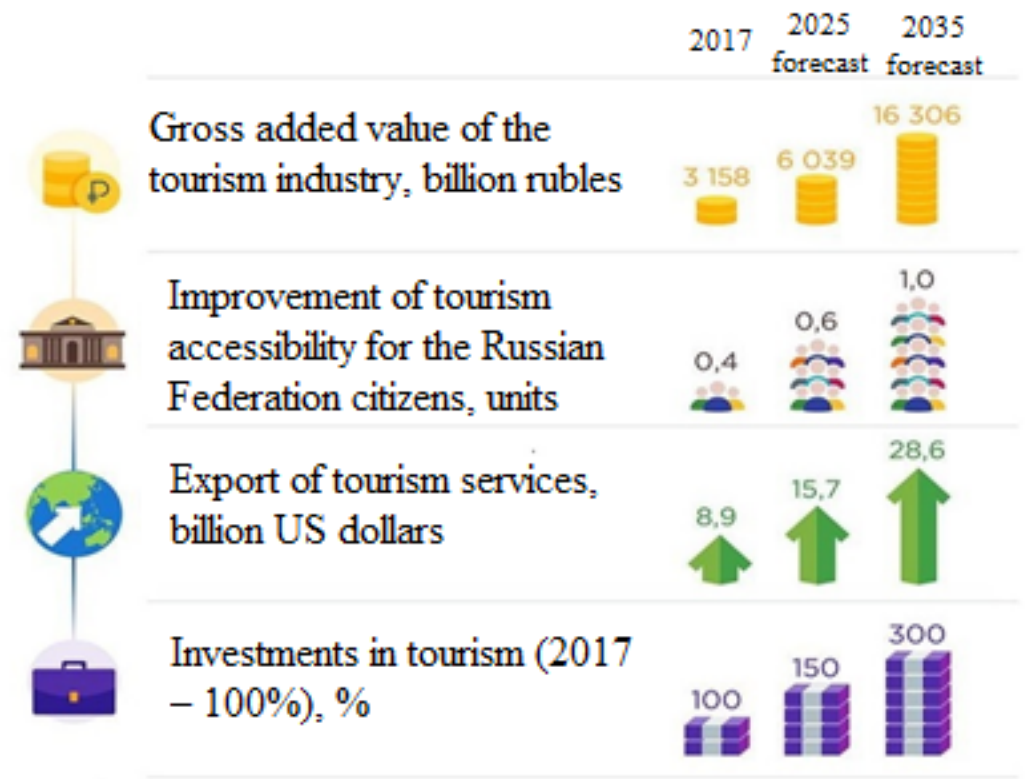

Figure 1. Key target indicators of tourism development in Russia until 2035.

Source: Federal Agency for Tourism of the Russian Federation, 2020

Thus, as a result of the Strategy implementation by 2035 , the gross value added of the tourism industry should increase by more than 5 times, the number of tourist trips made by one resident per year in his own country (the ratio of the number of RF citizens, placed in the CAF, to the population of Russia) should increase by more than 2 times, the export of tourist services - by more than 3 times, investments in tourism - by 3 times.

The Developed Strategy should solve the following main problems of the tourism and hospitality industry: the insufficiently high competitiveness of tourist products in the domestic and international markets, the low level of demand for tourist products from foreign and domestic tourists, the need to improve the system of regulating the tourism development.

It should be separately noted that in the context of the crisis caused by the pandemic that affected tourism in 2020, Russia will experience significant difficulties, as well as the whole world, in implementing the planned programs for the development of not only tourism but also the economy as a whole. Therefore, federal and regional tourism development programs will need to be objectively adjusted in the coming years. This fully applies to the Strategy of tourism development in the Russian Federation for the period until 2035, which defines tourism development until 2035.

One of the measures to implement the tourism development tools in the Strategy for the period up to 2035 is the development of statistical accounting in tourism. Let us consider organizing statistical observation in tourism in more detail, since the effective development of tourism, in the authors' opinion, is impossible without the availability of timely and reliable statistical information reflecting the state and development of the tourism and hospitality industry in Russia. It is also important that in 
recent years, active work has been carried out to unify statistical methodology and statistical tools with international standards, which will eventually allow for correct comparisons of statistical indicators in the tourism industry.

The authors will consider the main summary economic indicators (investment, finance, etc.) that characterize the state of this service sector to determine the structure of the types of economic activity in the tourism and hospitality industries.

The distribution of the number of organizations in the tourism and hospitality industry in the context of its economic activities is shown in Figure 2.

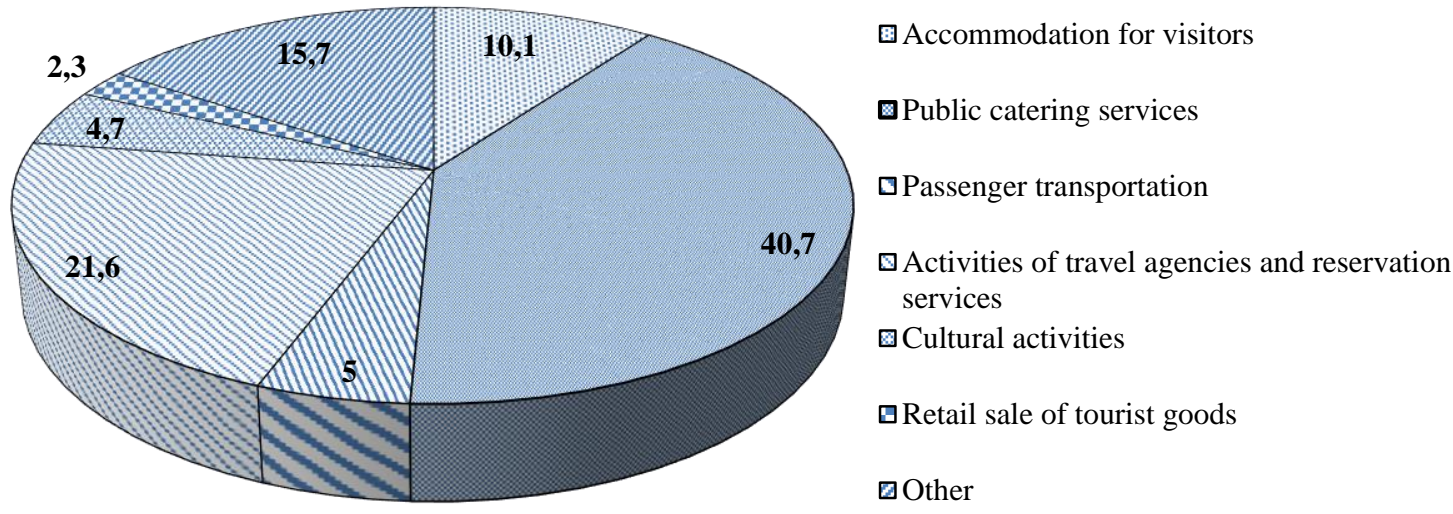

Figure 2. Distribution of the number of organizations by the collective grouping "Tourism" in the context of economic activities in $2018, \%$

Source: Federal Agency for Tourism of the Russian Federation, 2020

As shown in Figure 2, the largest number of enterprises and organizations in the tourism and hospitality industry is catering, followed by organizations of tourist services, other services, accommodation services, transportation services, cultural enterprises' services, and retail trade in tourist products.

However, by the amount of revenue (without VAT, excise taxes, and similar mandatory payments) in 2018 the first place is occupied by passenger transportation (59.8\%), followed by food services $(18.8 \%)$, other services $(8.0 \%)$, accommodation services $(7.1 \%)$, tourist services (3.6\%), services of cultural enterprises $(1.9 \%)$, retail trade of tourist goods $(0.9 \%)$ (Federal Agency for Tourism of the Russian Federation, 2020).

The following indicators of tourism statistics usually present official statistical information that characterizes the development of tourism in Russia:

- indicators of tourism development in Russia;

- key performance indicators of the CAF;

- key performance indicators of travel companies;

- selected indicators of tourism and hospitality industries;

- international comparisons.

The authors will analyze the official statistical information describing tourism development in the Russian Federation in recent years to characterize the social and economic development aspects of the tourism and hospitality industry.

Let us analyze the tourism development indicators in Russia for 2014-2018 (Table 2). 
Table 2.

Tourism development indicators in the Russian Federation for 2014-2018

\begin{tabular}{|c|c|c|c|c|c|}
\hline Indicators & 2014 & 2015 & 2016 & 2017 & 2018 \\
\hline $\begin{array}{l}\text { Share of gross value added of the tourism } \\
\text { industry in the GDP of the Russian } \\
\text { Federation, } \%\end{array}$ & 3.3 & 3.3 & 3.4 & 3.8 & $\ldots$ \\
\hline $\begin{array}{l}\text { Volume of tourist services rendered to } \\
\text { the population, billion rubles }\end{array}$ & 147.5 & 158.3 & 161.3 & 166.5 & 172.1 \\
\hline Volume of spa services, billion rubles & 92.3 & 110.5 & 120.0 & 112.3 & 124.8 \\
\hline $\begin{array}{l}\text { Volume of paid services of hotels and } \\
\text { similar accommodation facilities, billion } \\
\text { rubles }\end{array}$ & 175.7 & 189.0 & 213.3 & 219.9 & 255.7 \\
\hline Number of CAF, units & 15,590 & 20,135 & 20,534 & 25,292 & 28,072 \\
\hline Number of rooms in CAF, thousand units & 670.8 & 770.4 & 794.8 & 884.3 & 975.1 \\
\hline Number of seats in CAF, thousand units & $1,573.3$ & $1,762.6$ & $1,848.1$ & $2,167.9$ & $2,414.5$ \\
\hline $\begin{array}{l}\text { Number of overnight stays in CAF, } \\
\text { million units }\end{array}$ & 184.0 & 212.2 & 216.8 & 253.0 & 279.0 \\
\hline $\begin{array}{l}\text { Number of Russian citizens placed in } \\
\text { CAF, thousand people }\end{array}$ & $33,798.5$ & $43,656.9$ & $48,338.7$ & $53,534.4$ & $62,210.1$ \\
\hline $\begin{array}{l}\text { Number of foreign citizens placed in } \\
\text { CAF, thousand people }\end{array}$ & $4,607.9$ & $5,627.3$ & $6,092.2$ & $8,028.8$ & $11,483.8$ \\
\hline $\begin{array}{l}\text { Number of inbound tourist trips, } \\
\text { thousand trips }\end{array}$ & 25,438 & 26,852 & 24,571 & 24,390 & 24,551 \\
\hline $\begin{array}{l}\text { Number of outbound tourist trips, } \\
\text { thousand trips }\end{array}$ & 42,921 & 34,390 & 31,659 & 39,629 & 41,964 \\
\hline Number of tourist companies, units & 11,614 & 11,893 & 12,395 & 13,579 & 13,674 \\
\hline $\begin{array}{l}\text { Number of Russian citizens sent on tours } \\
\text { in Russia, thousand people }\end{array}$ & $1,974.2$ & $2,628.2$ & $3,284.2$ & $3,285.4$ & $3,374.6$ \\
\hline $\begin{array}{l}\text { Number of Russian citizens sent on } \\
\text { foreign tours, thousand people }\end{array}$ & $6,512.9$ & $5,261.0$ & $3,422.1$ & $5,630.0$ & $5,486.3$ \\
\hline $\begin{array}{l}\text { Travel services exports, billion US } \\
\text { dollars }\end{array}$ & 11.8 & 8.4 & 7.8 & 8.9 & 11.5 \\
\hline in $\%$ of total exports of services & 17.9 & 16.3 & 15.4 & 15.5 & 17.8 \\
\hline
\end{tabular}

Source: Federal Agency for Tourism of the Russian Federation, 2020

As shown in Table 2, in 2018, compared to 2014 , the volume of tourist services provided to the population increased by $16.7 \%$, which should be recognized as a reasonably good result in current conditions. Attention is drawn to the increase in indicators that characterize the development of the hotel industry. In particular, the volume of paid services of hotels and similar accommodation facilities for the reporting period increased by $45.3 \%$, the number of CAF - by $80.1 \%$, the number of rooms in the CAF by $45.4 \%$, the number of seats in the CAF - by $53.5 \%$, the number of Russian citizens placed in the CAF - by $84.1 \%$, the number of foreign citizens placed in the CAF - by $149.2 \%$. The above indicators demonstrate the dynamics of changes in the hotel industry since 2014.

Now let us look at the dynamics of indicators that characterize tourism development during the reporting period. In particular, the inbound tourist flow in 2018 was 24,551 thousand visits that correspond to a decline from 2014 to $3.5 \%$, the number of tourists visiting decreased by $2.2 \%$ of organized domestic tourists (travel through a travel agency) increased by $70.9 \%$, the number of citizens of the Russian Federation sent to tours abroad, amounted to 5,486.3 thousand (a decrease compared to 2014, 15.8\%), the number of travel agencies has declined $17.7 \%$ in total exports of travel services in 2018, the share of tourism services was $17.8 \%$.

Thus, from 2014 to 2018, the hospitality industry showed a higher growth rate than the tourism industry. In the authors' opinion, among other factors, this is since major international sports events were held in Russia during this time.

Let us also analyze the main indicators of CAF activity in Russia for 2014-2018.

The structure of the CAF by type is shown in Figure 3. 


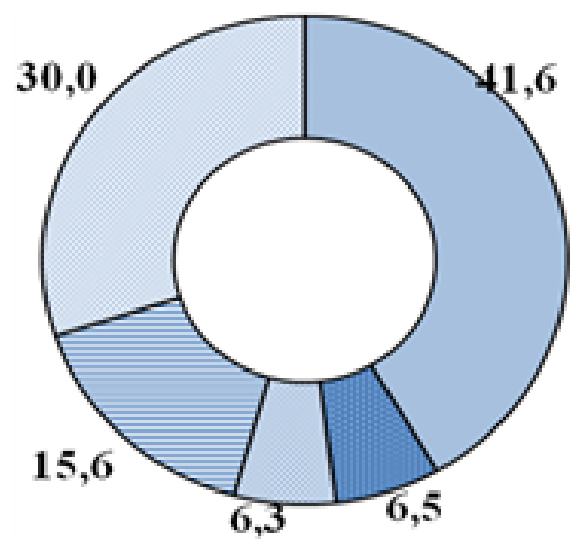

$\square$ Hotels

๑ Hostels

¿ Sanatoriums and resorts

Recreation organizations Others

Figure 3. Distribution of CAF in Russia by type in 2018, \%

Source: Federal Agency for Tourism of the Russian Federation, 2020

As can be seen from Figure 3, in Russia in 2018 , the largest share was made up of hotels $41.6 \%$, recreation organizations $-15.6 \%$, spa organizations $-6.3 \%$, hostels $-6.5 \%$, and other accommodation facilities $-30 \%$.
Consider the distribution of the number of Russian citizens staying in hotels in 2018 (Figure 4).
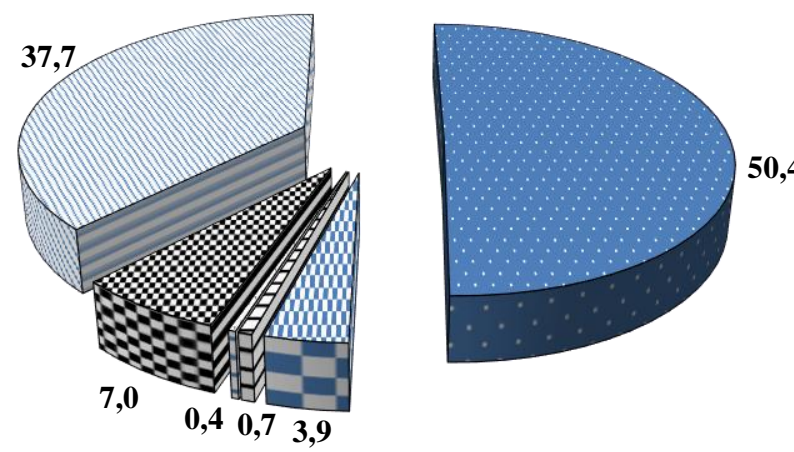

口vacation, leisure and recreation

Qeducation and vocational training

日health and wellness treatments

口religious/pilgrimage

Eshopping and other

口business and professional

Figure 4. Distribution of the number of Russian citizens placed in hotels due to travel purposes in $2018, \%$ Source: Federal Agency for Tourism of the Russian Federation, 2020

As follows from Figure 4, the largest number of Russian citizens staying in hotels traveled for leisure, vacation, and recreation $-50.4 \%$, for business and professional purposes $-37.7 \%$, for shopping $-7.0 \%$, for education and professional retraining $-3.9 \%$, for medical and wellness procedures $-0.7 \%$, for religious (pilgrimage) purposes $-0.4 \%$.

It should be noted that only in recent years, Russia began to study visitors according to the trip goals presented in Figure 4 (UNWTO method). In Russia, other travel purposes were traditionally used, for which tourists were studied.

Review of the main indicators of tourism firms for the period from 2014 to 2018. Consider the activities of Russian travel companies for 20142018 (Table 3). 


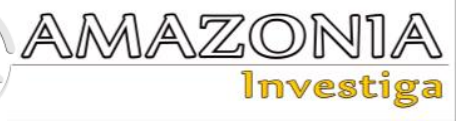

Table 3.

Activities of Russian travel companies in 2014-2018

\begin{tabular}{|c|c|c|c|c|c|}
\hline Indicators & 2014 & 2015 & 2016 & 2017 & 2018 \\
\hline $\begin{array}{l}\text { Number of tourist companies } \\
\text { including those carrying out the following } \\
\text { activities: }\end{array}$ & 11,614 & 11,893 & 12,395 & 13,579 & 13,674 \\
\hline tour operator & 445 & 349 & 549 & 723 & 751 \\
\hline travel agency & 9307 & 9701 & 9300 & 11,133 & 11,172 \\
\hline tour operator and travel agency & 1306 & 1159 & 1479 & 1723 & 1751 \\
\hline $\begin{array}{l}\text { Number of Russian tourists sent on tours, } \\
\text { thousand people } \\
\text { including: }\end{array}$ & 8487.1 & 7889.2 & 6706.3 & 8915.4 & 8860.9 \\
\hline across Russia & 1974.2 & 2628.2 & 3284.2 & 3285.4 & 3374.6 \\
\hline to foreign countries & 6512.9 & 5261.0 & 3422.1 & 5630.0 & 5486.3 \\
\hline $\begin{array}{l}\text { Funds received from the sale of tourist products, } \\
\text { billion rubles }\end{array}$ & 229.0 & 239.8 & 191.3 & 279.8 & 310.9 \\
\hline $\begin{array}{l}\text { Amount of commission, agency, and other } \\
\text { remuneration, billion rubles }\end{array}$ & 17.6 & 18.2 & 16.4 & 21.7 & 24.4 \\
\hline $\begin{array}{l}\text { Funds transferred to suppliers of tourist products } \\
\text { for services rendered outside the Russian } \\
\text { Federation, billion rubles }\end{array}$ & 173.7 & 165.5 & 111.9 & 198.7 & 226.1 \\
\hline
\end{tabular}

Source: Federal Agency for Tourism of the Russian Federation, 2020

As follows from Table 3, in 2018, the maximum number of travel agencies engaged in the travel agency, tour operator, or both types of activities was reached for the period from 2014. The number of tourists sent was the highest in 2017.
The largest amount of funds received from the sale of tourist products amounted to 310.9 billion rubles and was recorded in 2018 .

Now the individual indicators of the Russian tourism and hospitality sector for 2014-2018 are considered. Let' $s$ analyze the dynamics of paid services in the tourism and recreation industry in 2014-2018 (Table 4).

Table 4.

Paid services in the field of tourism and recreation in Russia for 2014-2018

\begin{tabular}{|c|c|c|c|c|c|}
\hline Type of service & 2014 & 2015 & 2016 & 2017 & 2018 \\
\hline $\begin{array}{l}\text { Paid services to the population - total, } \\
\text { million rubles, in actual prices }\end{array}$ & $7,467,521$ & $8,050,808$ & $8,636,277$ & $9,211,441$ & $9,703,358$ \\
\hline \multicolumn{6}{|l|}{ of these: } \\
\hline tourist services & 147,541 & 158,252 & 161,344 & 166,520 & 172,090 \\
\hline hotels and similar accommodation facilities & 175,709 & 188,992 & 213,288 & 219,916 & 255,708 \\
\hline health resorts & 92,300 & 110,513 & 120,009 & 112,305 & 124,783 \\
\hline \multicolumn{6}{|l|}{$\begin{array}{l}\text { Share in the total volume of paid services to } \\
\text { the population, } \%\end{array}$} \\
\hline tourist services & 2.0 & 2.0 & 1.9 & 1.8 & 1.8 \\
\hline hotels and similar accommodation facilities & 2.4 & 2.3 & 2.5 & 2.4 & 2.6 \\
\hline health resorts & 1.2 & 1.4 & 1.4 & 1.2 & 1.3 \\
\hline $\begin{array}{l}\text { Paid services to the population - total, in } \% \\
\text { of the previous year, at comparable prices } \\
\text { of these: }\end{array}$ & $101.0^{2)}$ & 98.9 & 100.7 & 101.4 & 101.4 \\
\hline tourist services & 94.6 & 96.0 & 95.0 & 99.6 & 100.5 \\
\hline hotels and similar accommodation facilities & 103.5 & 102.6 & 109.6 & 108.9 & 112.5 \\
\hline health resorts & 104.2 & 107.4 & 97.9 & 100.1 & 106.7 \\
\hline
\end{tabular}

Source: Federal Agency for Tourism of the Russian Federation, 2020 
As shown in Table 4, income from tourist services, hotel services, and similar accommodation facilities and spa services increased annually from 2014 to 2018. In the total volume of paid services to the population, the share of tourist services in 2018 was $1.8 \%$, hotel services, and similar accommodation facilities $-2.6 \%$, sanatorium and resort services $-1.3 \%$. Simultaneously, the share of tourist services in 2018 decreased by $0.2 \%$ compared to 2014 . These data indicate a small percentage of paid services in tourism and recreation in the total volume of paid services to the population.

Consider the structure of foreign nationals' distribution in the CAF by individual constituent entities of the Russian Federation (Figure 5).
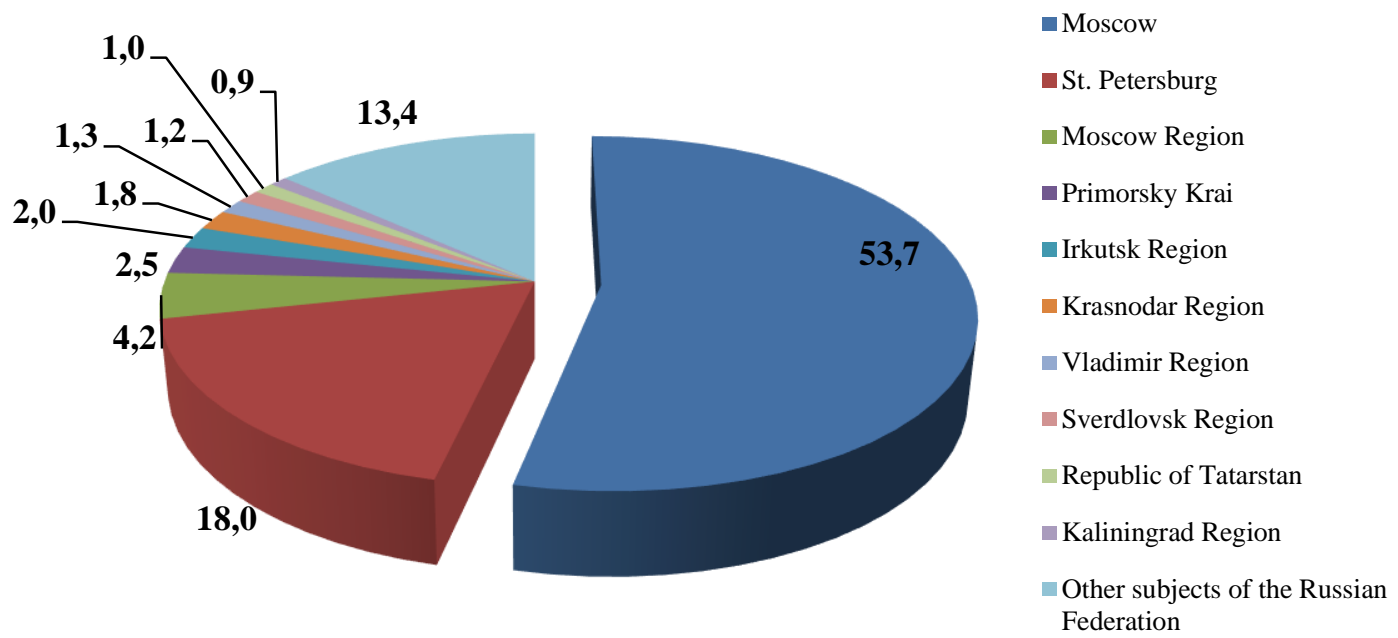

Figure 5. Distribution of the number of foreign citizens placed in the CAF by the subjects of the Russian Federation in 2018, \%

Source: Federal Agency for Tourism of the Russian Federation, 2020

As follows from Figure 5, the largest number of foreigners in 2018 were located in Moscow $(53.7 \%)$, St. Petersburg (18\%), other subjects (13.4\%), the Moscow Region (4.2\%), Primorye Territory (2.5\%), Krasnodar Territory (2\%), Irkutsk Region (1.8\%), Rostov Region (1.3\%), the Republic of Tatarstan (1.2\%), Sverdlovsk Region (1.0\%), and Vladimir Region $(0.9 \%)$.

Consider the indicators of international comparison in the field of tourism and hospitality. International tourist arrivals by a foreign country are shown in Table 5.

Table 5.

International tourist arrivals in foreign countries for 2014-2017, million arrivals.

\begin{tabular}{lcccc}
\hline \multicolumn{1}{c}{ Countries } & 2014 & 2015 & 2016 & 2017 \\
\hline $\begin{array}{l}\text { Total, million arrivals } \\
\text { of these, by country: }\end{array}$ & 1133 & 1189 & 1235 & 1323 \\
Australia & & & & \\
Austria & 6.9 & 7.5 & 8.3 & 8.8 \\
Germany & 25.3 & 26.7 & 28.1 & 29.5 \\
Greece & 33.0 & 35.0 & 35.6 & 37.5 \\
Spain & 22.0 & 23.6 & 24.8 & 27.2 \\
Italy & 64.9 & 68.2 & 75.3 & 81.8 \\
Canada & 48.6 & 50.7 & 52.4 & 58.3 \\
China & 16.5 & 18.0 & 20.0 & 20.8 \\
Mexico & 55.6 & 56.9 & 59.3 & 60.7 \\
Russia & 29.3 & 32.1 & 35.1 & 39.3 \\
UK & 25.4 & 26.9 & 24.6 & 24.4 \\
Turkey & 2.6 & 34.4 & 35.8 & 37.7 \\
France & 39.8 & 39.5 & 30.3 & 37.6 \\
Switzerland & 83.7 & 84.5 & 82.7 & 86.9 \\
\hline Source: Federal Agency & 9.2 & 9.3 & 9.2 & 9.9 \\
\hline
\end{tabular}

Source: Federal Agency for Tourism of the Russian Federation, 2020 


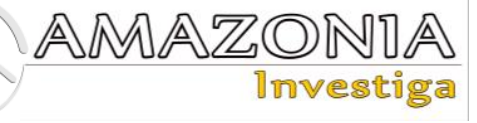

Table 5 shows international inbound tourism statistics based on UNWTO data. At the same time, citizens of the country living abroad and crew members are excluded. Arrivals of foreign tourists placed only in hotels and similar paid accommodation facilities are taken into account. Seasonal workers and border guards are excluded. Citizens of countries living abroad are included.

As can be seen, most tourists in 2017 visited France (86 million arrivals), Spain (81.8 million arrivals), China (60.7 million), Italy (58.3), etc. The indicators of Russia (24.4 million arrivals) in this series look relatively modest. Also, the degree of tourism development in Russia in 2018 can be estimated by comparing the number of domestic and foreign tourists per 100 residents of the Russian Federation compared to some of the leading countries in tourism (Figure 6).

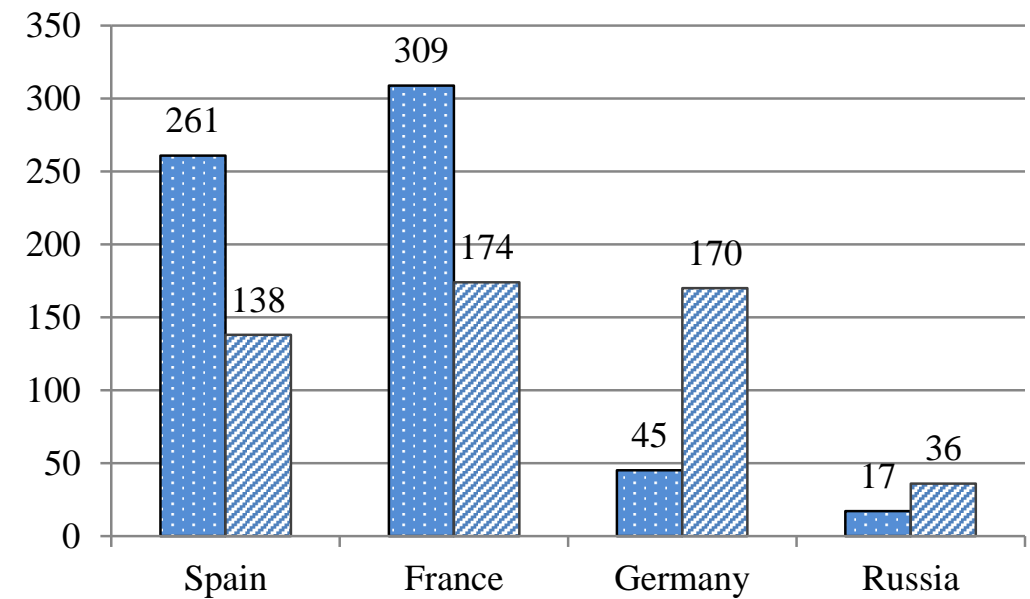

$\square$ Foreign tourists

口Domestic tourists

Figure 6. The number of domestic and foreign tourists per 100 inhabitants in different countries in 2018, people

Source: Federal Agency for Tourism of the Russian Federation, 2020

Thus, the data in Figure 6 confirm that Russia is inferior to the leading European countries in terms of domestic and foreign tourists' ratio per 100 inhabitants. This fact proves the need for both more intensive tourism development in the Russian Federation's territory and more active attraction of tourist flows from abroad.

Thus, after analyzing the social and economic factors of the development of tourism and hospitality industries in the Russian Federation for 2014-2018, the conclusion is formulated: the Russian Federation should intensify tourism development. There are negative factors that hinder growth in the tourism and hospitality industry. According to some estimates, only $20 \%$ of Russia's tourism potential is being used so far (Andrades \& Dimanche, 2017). In these conditions, it is necessary to develop social tourism, create conditions for the availability of tourist and excursion services for different categories of Russian citizens.

\section{Conclusions}

Considering the economic impact of tourism on the economy, one should not forget the social aspect of the tourism industry in Russia (employment, development of social tourism, creating a barrier-free environment for tourists, accessible treatment in sanatoriums and boarding houses on medical grounds for various categories of citizens in need, recreation as a factor in the restoration of human strength during a tourist trip or journey).

Besides, various studies indicate that during the financial crisis, the number of market participants is significantly reduced, many market participants are cooperating with larger players and get appropriate support for further work. Many participants are also characterized by a desire to diversify their activities to work effectively. Thus, the establishment of partnerships between participants who are leaders in the tourism sector is one of the most effective ways to develop tourism in the Russian Federation regions.

\section{Bibliographic references}

Andrades, L. \& Dimanche, F. (2017). Destination competitiveness and tourism development in Russia: Issues and challenges. Tourism Management, 62(C), https://doi.org/10.1016/j.tourman.2017.05.008 
Bianchi, R.V. (2018). The political economy of tourism development: A critical review. Annals of Tourism Research, 70, 88-102. https://doi.org/10.1016/j.annals.2017.08.005 Brida, J.G., Matesanz, B.D., \& Segarraa, G.V. (2020). On the empirical relationship between tourism and economic growth. Tourism Management, $\quad 81, \quad 104131$. https://doi.org/10.1016/j.tourman.2020.104131

Briedenhann, J., \& Wickens, E. (2004). Tourism routes as a tool for the economic development of rural areas: Vibrant hope or impossible dream? Tourism Management, 25, 71-79. http://dx.doi.org/10.1016/S0261-

5177(03)00063-3.

Burns, P. (1998). Tourism in Russia: background and structure. Tourism Management, $19 \quad$ (6), 555-565. https://doi.org/10.1016/S0261-5177(98)00060-0 Chen, C.-F., \& Chiou-Wei, S.Z. (2009). Tourism expansion, tourism uncertainty, and economic growth: New evidence from Taiwan and Korea. Tourism Management, 30 (6), 812818.

http://dx.doi.org/10.1016/j.tourman.2008.12.013 Chibir, E. and Shirko, T. (2015). Event Tourism in Russian Region: Opportunity for Small-scale Business Growth. Procedia Economics and Finance, 26, 183-187. https://doi.org/10.1016/S2212-5671(15)00916-8 Croes, R., \& Venegas, M. Cr. (2008). Cointegration and causality between tourism and poverty reduction. Journal of Travel Research, $47 \quad$ (1), 94-103. http://dx.doi.org/10.1177/0047287507312429

Directive № 2129-R «Strategy of tourism development in the Russian Federation for the period until 2035». Collection of Laws of the Russian Federation, Moscow, Russia, 22 September, 2019.

Federal Agency for Tourism of the Russian Federation (2020). Statistical data on the tourism industry in Russia for the period 20182020. Available at: http://opendata.tourism.gov.ru/opendata (in Russian)

Fedorova, S., Fedorova, G., \& Konopleva, N. (2020). Functional typological structure of ethnic and cultural tourism in the Republic of Sakha (Yakutia). Amazonia Investiga, 9(25), 71-77. Retrieved from https://amazoniainvestiga.info/index.php/amazo nia/article/view/1028

Gorbunov, A., Kolyadin, A., Burnyasheva, L., Gazgireeva, L., \& Kosenko, O. (2018). Tourist and recreational clusters as organizational and economic mechanism of control of formation and development of the innovative capacity of the North Caucasus Federal District. Amazonia
Investiga, 7(17), 60-71. Retrieved from https://amazoniainvestiga.info/index.php/amazo nia/article/view/326

Gorbuntsova, T., Dobsonb, S., and Palmerc, N. (2019). Diverse geographies of power and spatial production: Tourism industry development in the Yamal Peninsula, Northern Siberia. Annals of Tourism Research, 76, 67-79. https://doi.org/10.1016/j.annals.2019.03.006

Holzner, M. (2011). Tourism and economic development: The beach disease? Tourism Management, $32 \quad$ (4), 922-933. http://dx.doi.org/10.1016/j.tourman.2010.08.007 Jakosuo, K. (2011). Russia and the Russian tourist in Finnish tourism strategies-the case of the Karelian region. Procedia - Social and Behavioral Sciences, 24, 1003-1013. https://doi.org/10.1016/j.sbspro.2011.09.015

Konovalova, E.E., Yudina, E.V., Bushueva, I.V., Ukhina, T.V. \& Lebedev, K.A. (2018). Forming Approaches to Strategic Management and Development of Tourism and Hospitality Industry in the Regions. Journal of Environmental Management and Tourism, 9 (2), 241-247.

https://doi.org/10.14505//jemt.v9.2(26).03

Kulgachev, I.P., Zaitseva, N.A., Larionova, A.A., Ivanova, E.V., Gladilin V.A. and Zhenzhebir, V.N. (2018). The Main Directions of Stimulating the Development of Inbound Tourism in the Russian Federation. Espacios, 39 (22), 10.

Makkonenab, T., Williamsc, A.M., Weidenfeldd, A., and Kaistoe, V. (2018). Crossborder knowledge transfer and innovation in the European neighbourhood: Tourism cooperation at the Finnish-Russian border. Tourism Management, 68, 140-151. https://doi.org/10.1016/j.tourman.2018.03.008 Matarrita-Cascante, D. (2010). Changing communities, community satisfaction, and quality of life: A view of multiple perceived indicators. Social Indicators Research, 98, 105127. http://dx.doi.org/10.1007/s11205-0099520-z.

Pinkovetskaia, I., Arbeláez-Campillo, D., Rojas-Bahamón, M., \& Veas Iniesta, D. (2020). Motivation of new entrepreneurs in modern economies. Amazonia Investiga, 9(29), 368-373.

https://doi.org/10.34069/AI/2020.29.05.41

Poddubnaya, T., Zadneprovskaya, E., Dzhum, T., \& Khatit, F. (2020). Using the electronic information and educational environment of the university in the training of tourism industry workers. Amazonia Investiga, 9(28), 249-259. https://doi.org/10.34069/AI/2020.28.04.28 


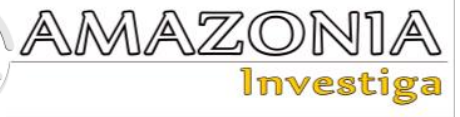

Resolution No.644 «Development of domestic and inbound tourism in the Russian Federation (2011 - 2018)». Collection of Laws of the Russian Federation, Moscow, Russia, 22 August, 2011.

Studzienieckia, T., Palmowskib, T., and Korneevetsc, V. (2016). The System of Crossborder Tourism in the Polish-Russian Borderland. Procedia Economics and Finance, 39, 545-552. https://doi.org/10.1016/S22125671(16)30298-2

Tang, C.F., \& Tan, E.C. (2015). Does tourism effectively stimulate Malaysia's economic growth? Tourism Management, 46, 158-163. http://dx.doi.org/10.1016/j.tourman.2014.06.020
Tugcu, C. T. (2014). Tourism and economic growth nexus revisited: A panel causality analysis for the case of the Mediterranean region. Tourism Management, 42, 207-212. http://dx.doi.org/10.1016/j.tourman.2013.12.007 Yudina, E.V. and Bushueva I.V. (2020). Current state and analysis of tourism development in Russia until 2035. Revista Inclusiones, 7 (S2-2), 350-356.

Zhao, X. (1994). Barter tourism along the China-Russia border. Annals of Tourism Research, $21 \quad$ (2), 401-403. https://doi.org/10.1016/0160-7383(94)90057-4 